\title{
PERFORMANCE OF WEST AFRICAN DWARF (WAD) GOATS FED TRIDAX AND SIAM WEED IN FICUS BASED DIETS
}

\author{
Okukpe K.M., Adeloye A.A., Badmos A.H.A., Adeyemi K.D and Olaniran T.O. \\ 'Department of Animal Production, University of Ilorin, Nigeria. \\ Email: Okukpek@yahoo.com;
}

\begin{abstract}
Twelve West African dwarf goats weighing between $4.5 \mathrm{~kg}$ to $5.5 \mathrm{~kg}$ were used to study the effect replacement of Tridax and Siam weed in Ficus based diet. The goats were divided into three dietary treatments with attention to the body weights with four replicate per treatment. The diets were fed for a period of 25 days in order to investigate the influence of the replaced forage mixture on feed intake and nutrient digestibility, also on the level of the serum metabolites as factor of influence.

Goats maintained on Ficus-Tridax forage mixture consumed more dry matter than goats fed Ficus only and Ficus-Siam mixture. The average values were 186.57g/day for Ficus, 202.56g/day for Ficus-Tridax mixture, and 145.0g/day for Ficus-Siam mixture pergoat.

The nature of the feed influence the digestibilities of the nutrients, the relative values of which were statistically $(p<0.05)$ significant. The values of crude fiber digestibility in the treatment were not significantly different $(p<0.05)$. The result of serum metabolites anaylsed showed no statistical difference ( $p<0.05)$, so all the forage feeds tested could cause no harm of significant measure to the animals, results of this study suggest that Tridax can be effectively used to feed small ruminant most especially the WAD goat and it serves as alternative browse plant for the scarce forages during the dry season.
\end{abstract}

\section{INTRODUCTION}

Feeding accounts for more than $60 \%$ of total production cost (Schoeminon, 2003). Goats can utilize grass for tissue development, the quality and quantity of which fluctuate with seasons and stage of maturity. The relative importance of browses in ruminant nutrition specifically during the dry season period cannot be overemphasized. The leaves are ever green and sometimes used for zero-grazing. Extensive use of some known browse plants such as Leucaena are hindered by the presence of antinutrients. Hence the need to look out for browse plants that are nutritious and with little or no inhibitious factor in them. Ficus species are evergreen browse plants that grow in the various ecological zones of Nigeria and are available all the year round. Both Ficus religiosa and Ficus polita have been found to be acceptable by goats and degradable in rumen (Bamikole et al., 2003; Ajayi et al., 2005.) Various researches have been done that showed that ruminants performed better when fed grass/legume combination. However, there is no information on the performance of goats fed various combinations of browse plants. 
Blood constituents are widely use in nutritional evaluations and survey of animals Feeds have been reported to have measurable effect on blood components (Olorode et al., 1995). Blood contain a myriad of metabolites and other constituents, which provide a valuable medium for clinical investigation and nutritional status of man and animals. Schildneck et al (1980) and Ngodigha et al (1999) found that crude oil contaminated feeds altered the haemoglobin $(\mathrm{Hb})$, packed cell volume (PVC), neutrophil, lymphocytes and white blood cells (WBC) of goats. The objective of the study was to determine the performance characteristics and serum biochemistry of WAD goats fed tridax and siam weed in ficus based diets

\section{MATERIALSAND METHODS}

\section{Experimental Animals and Management}

The experiment was carried out at the small ruminant unit of the Teaching and Research Farm of the University of llorin, llorin, Kwara State, Nigeria. Twelve post weaned female West African Dwarf goats with mean initial body weight of $7.00 \pm 1.00 \mathrm{kgand}$ between $8-10$ months old were purchased from the goat market in llorin metropolis. The goats were dewormed with Levamisole (Kepro B.V. Holland, $1 \mathrm{~m} 1$ per $20 \mathrm{~kg}$ body weight) and long acting oxytetracycline 200LA (invesa, Spain $1 \mathrm{~m} 1 \mathrm{per} 10 \mathrm{~kg}$ body weight) was also administered. Water and feed were supplied ad libitum at $3 \%$ body weight for feed.

The animals were allocated to experimental diets and metabolism cages in a completely randomized design fitted with devices for separate faecal and urinal collections. They were allowed 7 days adaptation period before sample collection which lasted for another seven days.

Total quantities of faeces voided by each animal collected and about 105 aliquot of each days collection was bulked and kept for analysis. About $2 \mathrm{ml}$ of blood was collected by jugular vein puncture before feeding in the morning into plain container, allowed to cloth and centrifuged at 2000 revolution per $\mathrm{mm}$ for 15 minutes. Collected samples of blood were analysed for blood urea, glucose, glutamateoxalocetic-transaminase (GOT) and glutamylpyruvate transaminase (GPT).

\section{Collection of forages}

The young forage materials Ficus, Tridax and Siam were collected within the universityof llorin community, allowed to wilt and dried under shade to maintain the greenish colouration. The dried forage were packed in jute sacks and stored.

\section{Chemical analysis}

The forage materials were oven dried at $65^{\circ} \mathrm{C}$ until a constant weight was obtained for dry matter determination. Crude protein, crude fibre, ether extract and ash were analysed according to AOAC (2002). Blood samples were collected from animals in each group for determination of serum biochemical indices such as blood urea, glucose, glutamateoxacetic transaminase (GOT), 
glutamylpyruvic transaminase (GPT) as described by Jain (1986). The faeces collected from each experimental group were analysed for proximate composition according to the methods outlined by AOAC (2002).

\section{Statistical analysis}

Data collected were analysed using analysis of variance of statistical analysis software (SAS, 1999) and significant treatment means were separated using Duncan's Multiple Range test (Duncan, 1955) procedure of the same software.

\section{RESULTSAND DISCUSSION}

The proximate composition of the experimental diets Ficus, Ficus + Tridax, Ficus + Siam are as shown in table 1. The cured protein in the diet was different but not significant. The ether extract reduce with the addition of other forages to Ficus while crude protein and nitrogen free extract (NFE) increases with addition of other forages to Ficus. The average daily dry matter intake as shown in table 2 reveals that animals on Ficus Tridax mixture consumed more dry matter (202.56g/day followed by those on Ficus and Ficus-Siam mixture with $186.57 \mathrm{~g} /$ day and $145.0 \mathrm{~g} / \mathrm{day}$ respectively. Goats fed Ficus-Tridax mixture had the highest nutrient intake for most of the nutrients studied. The goats fed Ficus-Siam has the lowest nutrient intake and the analysis showed that there were differences in the nutrient intakes of the three diets $(p<0.05)$. the effect of the dietary treatment on apparent nutrient digestibility did not follow a definite pattern (Table 30. however, Ficus-Tridax mixture had the highest crude protein digestibility $969.08 \%$ ) followed by Ficus $(63.52 \%)$ while Ficus-Siam mixture $(60.13 \%)$ respectively.

The ash digestibility followed the same way with Ficus-Tridax having the highest $(61.76 \%)$ followed by Ficus (58.95\%) and Ficus-Siam mixture (43.21\%) respectively. However, the apparent nutrient of Nitrogen free extract was highest in Ficus (86.65\%), followed by Ficus-Siam mixture $(83.23 \%)$ and Ficus Tridax mixture $(74.66 \%)$ respectively. The crude fibre digestibility, though not significant was highest in Ficus-Siam mixture $(50.11 \%)$ followed by Ficus $(45.08 \%)$ and FicusTridax mixture $(44.90 \%)$ respectively.

Serum metabolites as influenced by the forage mixture fed to the WAD goats are shown in table 5. The GOT/AST of Ficus-Siam mixture was the highest (92.25) followed by Ficus-Tridax mixture and Ficus respectively but not significantly different $(P<0.05)$. While the GPT/ALT of FicusTridax mixture was highest (16.75), followed by Ficus (16.67) and Ficus-Siam mixture (15.05), respectively. However Urea was highest in Ficus-Siam 2.18 and lowest in Ficus (2.00) while glucose was lowest in Ficus; Ficus-Tridax and Ficus Siam had the same value, but not significantly differently different $(P<0.05)$.

The proximate composition of Ficus, Ficus-Tridax and Ficus Siam has good nutrient profile that could guarantee better productive response in goats. The CP content exceeds the $8 \%$ 
that can provide the minimum ammonia levels required for microbial activity (Norton, 1994). Though the values of CP in Ficus used differ from those reported by Oji et al, 2002 (16.63\% CP Ficus) expasperata); Bamikole et al 2003, 2004a (13\%CP Ficus religiosa and 20.5\%CP Ficus Thronningii); Ajayi et al 2005 (24.88\% CP Ficus Thonningii) and Maigandi and Wasagu, 2002 $(9.50 \%$ CP Ficus sycomorus); This variability in nutrient composition could be attributed to various factors such as species, plant age, harvesting regime, season and location. These factors should be considered when carrying out the chemical evaluation of fodder trees. The low CF in browse plant enhances the amount of energy available, sometimes making it double the amount of energy in dry grasses (Ajayi et al., 2005), this must have resulted in the better performance of Ficus-Tridax mixture with low CF but high NFE intake. The high digestibility values reported for the nutrient except crude fibre suggested that the forage mixture, were highly degraded in the rumen of the goat.

The high CP digestibility of Ficus-Tridax mixture indicate that protein digestibility increases with supplementation of Ficus with Tridax procumbens. This shows that Tridax leaves were more palatable and acceptable to the goats as feed. The low feed intake and nutrient digestibility observed in Ficus-Siam mixture could be attributed to the non-palatability and poor acceptance of Siam weed (chromolena odorata) thereby causing a reduced feed intake and nutrient utilization. This is an indication that adequate combination of browse plants could promo0te better digestibility of nutrients. This is consistent with previous studies involving Panicum maximum with Leucaena leucocephala (Adejumo, 1987), Maize stover with Acacia angustissima or Calliandra colothyrsus (Masama et al., 1997) and Pannicum maximum with Ficus religiosa (Bamikole etal., 2003).

The serum metabolites analysed shows no significant difference $(P<0.05)$ which could be that the forage mixture do not have variant effect in the goats and can be said to be safe for ruminant consumption. The mean values obtained for GPT are with the range reported by Daramola et al (2005), but are higher compared to the values reported by Wilson and Mead (1978). This trend may be due to the feed regime the animals were subjected to as no supplement was provided. The Urea level was also within the mean range reported by Daramola et al (2005) and the low level of serum urea obtained in this study compared with other small ruminant species (Wilson and Mead, 1978). This indicates the physiological basis for the superiority of WAD goat in its digestive capacity, efficiency of nitrogen utilization, Urea recycling and nitrogen conservation (Schoenion, 2003). The mean value of glucose observed were all within the range of normal blood glucose content for goat, and probably show that enough energy was made available to the goat since serum glucose is an estimation of blood sugar content.

This research shows a wide variation in the concentration of both alkaline phosphatase and transaminases (SGPT and SGOT). 


\section{CONCLUSION}

From the result of the experiment, it was observed that the replacement of Ficus with Tridax in a diet of WAD goats shows increasing effect on the level of feed intake and nutrient digestibility. In addition, the use of the forage mixture does not have any harmful effect on the health of the animal as observed from the result of serum metabolites analysis. So the use of Tridax as a browse plant can be recommended to feed goat and to solve the problem often encountered due to scarcity of feed for ruminant. The use of nutrient supplement should also be encouraged in small ruminant production.

\section{REFERENCES}

Adejumo, J.O., (1987): Effects of graded levels of Leucaena leucocepphala CV Cunninghma on feed intake ad growth of WestAfrican Dwarf goats. J. Amin Prod. Res 7 (1), 65.73.

Ajayi, D.A.; Adeneye, J.A and Ajayi F.T. (2005). Intake and Nutrient utilization of West African Dwarf Goats Fed Mango (Mangifera indica), Ficus (Ficus thonningii), Gliricidia sepium) Foliages and Guinea Grass (Panicum maximum). World Journal of Agricultural Science $1(2): 184-189$.

AOAC (2002). Official Methods of Analysis, Association of Official Analytical Chemists, $17^{\text {th }}$ Edition, Washington DC, USA.

Bamikole, M.A.; Babayemi, O.J.; Arigbede, O.M. and Ikhatua, U.J. (2003). Nutritive value of Ficus religiosa in WestAfrican dwarf goats. J. Anim Feed Sci. Tech. 105:71-79.

Bamikole, M.A.; Ikhatua, U.J.; Ajulo, M.T. and Oseji, A.C. (2004a). Feed utilization potential of West African Dwarf Goats Fed different proportions of Ficus Thronningii and Panicum maximum proceedings $29^{\text {th }}$ Ann. Conf. NSAP, 29:336-360.

Daramola, J.O.: Adeloye A.A.; Fatoba T.A, and Soladoye, (2005). Haematological and blood parameters of West Africa Dwarf Goat. Research for Rural development, Vol Retrieved from http//www.cipaw.org. 17/8/dawal 17095.html.

Duncan, D.B. (1955). Multiple Range and Multiple F test, Biometrics 11:1-42.

Maigandi, S.A. and Wasagu, A.A. (2002). Intake and digestibility of Nutrients by Yankassa rams fed varying levels of Ficus sycomorus (Baure) leaves. Proc. $27^{\text {th }}$ Ann. Conf. NSAP. Eds V.AAletor and G.E Onibi 182-184. 
Masam E; Topps, J.H; Ngongoni, N.T.: Maasdorp B.V., 1997 Effect of Supplementation with forage from the tree-legumes Acacia augustissima, Cajanus cajan, Caliandra calothyrsusu and Leucaena leucocephala on feed intake, digestibility and nitrogen metabolism of sheep given maize stover and libutum. Anim Feed Sci. Tech. 69,233240.

Ngodigha, E.M; Olayimika, F: Oruwari, B.M. Ekweonzor, I.K. and Wekhe S.N. (1999). Toxic effects of crude oil on blood of West African Dwarf goats. Proc. Of NSAP $27^{\text {th }}$ Annual Conf. 105-108.

Norton, B.W, (1994). Anti nutritive and toxic factors in forage tree legumes in tropical Agriculture, 202-215 (R.C Gutteridge and H.M. Shelton, eds). Wallingford, Oxford: CAB International.

Oji, U.I.; Larbi A. and Akele, S.A. (2002). Nutritional potential of common shrubs of the Niger Delta as ruminant feed. Proceedings $27^{\text {th }}$ Ann. Conf. NSAF Eds: VAS Aletor and GE Onibi 69.

Olorode. B.R; Ajagbonna, O.P and Babatunde G.M. (1995). Comparison of air dried poultry droppings in boiler rations. Effects on performance, organ weight and haematological parameters. Int J. Anim Sci. 10:289-293.

SAS Institute (1999). SAS/STAT. User's guide version 8 for windows. SAS Institute Inc. Cary, NC. USA.

Schildneck, E.D; Edger, S.A and Givens, S.V. (1980). Effects of casaloicid (0.0125\%) in combination with rozarsone on lesion reduction and oocyst suppression in chicken infected with Eimeria tenella field isolates. Poult. Sci. 59:1145-1147.

Schoeminon. S. (2003). An Introduction of feeding. Small ruminants. Westerns Maryland Cooperative Extension 211-212.

Wilson. P.M. Mead, R.K. (1978). Blood profile as a guide to Nutritional status in animal OCCA pub 1 Br. Soc. Anim Prod.155-162. 
Okukpe, Adeleye, Badmos, Adeyemi and Olaniran

Table 1: Proximate Composition of Experimental Diets*

\begin{tabular}{|c|c|c|c|c|}
\hline Composition & Ficus & Ficus + Tridax & Ficus+Siam & \\
\hline$(\%)$ & 100 & $60 \quad 40$ & 60 & 40 \\
\hline Dry matter & 94.45 & 92.50 & 92.00 & \\
\hline Crude protein & 15.09 & 15.97 & 16.41 & \\
\hline Ether extract & 5.54 & 4.55 & 4.01 & \\
\hline Ash & 17.31 & 17.25 & 11.73 & \\
\hline Crude fiber & 15.06 & 13.73 & 14.44 & \\
\hline Nitrogen free extract & 41.50 & 41.00 & 45.41 & \\
\hline
\end{tabular}

${ }^{*}$ All values are on as fed

Table 2: $\quad$ Feed and Nutrient intake as influenced by the

\begin{tabular}{lllll}
\hline Composition & Ficus & Ficus + Tridax & Ficus+Siam & S.E \\
\hline Feed intake & $186.56^{\mathrm{b}}$ & $202.56^{\mathrm{c}}$ & $145.00^{\mathrm{a}}$ & 2.55 \\
Crude protein & $28.16^{\mathrm{c}}$ & $32.37^{\mathrm{b}}$ & $23.00^{\mathrm{a}}$ & 0.41 \\
Ash & $32.29^{\mathrm{a}}$ & $38.98^{\mathrm{c}}$ & $17.01^{\mathrm{b}}$ & 0.36 \\
Nitrogen free extract & $77.41^{\mathrm{b}}$ & $3.10^{\mathrm{c}}$ & $65.85^{\mathrm{a}}$ & 0.13 \\
Crude fiber & $28.11^{\mathrm{ac}}$ & $27.80^{\mathrm{a}}$ & $20.94^{\mathrm{b}}$ & 0.36 \\
\hline
\end{tabular}

Values in the same row with different superscripts are significantly $(p<0.05)$ different.

Table 3:Feed and Nutrient digestibility as influenced by the Diets

\begin{tabular}{lllll}
\hline Parameter & Ficus & Ficus+Tridax & Ficus-Siam & S.E \\
\hline Feed intake & $69.31^{\mathrm{b}}$ & $69.20^{\mathrm{b}}$ & $62.09^{\mathrm{a}}$ & 1.97 \\
Crude Protein & $63.52^{\mathrm{b}}$ & $69.08^{\mathrm{a}}$ & $60.13^{\mathrm{c}}$ & 1.37 \\
Ash & $58.95^{\mathrm{b}}$ & $61.76^{\mathrm{b}}$ & $43.21^{\mathrm{a}}$ & 3.39 \\
Nitrogen free extract & $86.65^{\mathrm{a}}$ & $74.66^{\mathrm{c}}$ & $83.23^{\mathrm{b}}$ & 0.98 \\
Crude fiber & 45.08 & 44.90 & 50.11 & 2.48 \\
\hline
\end{tabular}

Values in the same row with different superscripts are 
Okukpe, Adeleye, Badmos, Adeyemi and Olaniran

Table 4: Serum Biochemical indices of WAD goats as influenced by the Diets

\begin{tabular}{lllll}
\hline Parameters & & Ficus & Ficus+Tridax & Ficus+Siam \\
S.E & & & & \\
GOT/AST (iu/1) & 85.50 & 91.50 & 92.25 & 2.01 \\
GPT/ALT (iu/1) & 16.67 & 16.75 & 15.50 & 2.76 \\
UREA (mmol/1) & 2.00 & 2.13 & 2.18 & 0.47 \\
GLUCOSE (mm01/1) & 3.90 & 4.00 & 4.00 & 0.07 \\
\hline
\end{tabular}

GOT = Glutamateoxacetic transaminase

AST $=$ Aspartate aminotransferase

GPT = Glutamyl phynavic transminase

$\mathrm{ALT}=$ Alanine aminotransferase 